\title{
Prostate cancer diagnosis by detection of uPM3 in urine
}

\author{
Prateek $K^{1}$, B Sivaramakrishna ${ }^{2}$, Rastogi $V^{3}$ \\ ${ }^{1}$ Dr. Kinra Prateek, Professor, AFMC, Pune, ${ }^{2}$ Dr. B Sivaramakrishna, Sr Adv (Surg \& Urosurg) Command Hospital \\ (EC), Kolkata; ${ }^{3}$ Dr. Rastogi V, Sr Adv Radiology, Army Hospital RR, Delhi.
}

Address for Correspondence: Dr Prateek Kinra, Professor, Department of Pathology, AFMC, Wanowrie, Pune. Email id: pkinra_in@yahoo.com,

\begin{abstract}
Background: The widespread acceptance of serum PSA testing for the early detection of prostate cancer has been hampered by the low specificity and unnecessary biopsies. Methods: This study was carried out to detect prostate cancers in patients with equivocal PSA values using RT-PCR (Reverse transciptase- polymerase chain reaction) to detect the uPM3 (urinary protein M3) in post prostatic massage urine samples. uPM3 is a mRNA released in prostate cancer patients due to the presence of the oncogene DD3 also called as PCA3 on chromosome 9. Results: There were a total of 27 cases of prostate carcinoma and 33 cases of PIN (prostate intraepithelial neoplasia) detected in this study. The sample collection accuracy depending on presence of beta 2 microglobulin (housekeping gene) band was $88 \%$. The sensitivity and specificity of uPM3 keeping histopathology as gold standard was $85.18 \%$ and $98.78 \%$ respectively. Positive predictive value was $88.46 \%$ and negative predictive value was $98.38 \%$ which is much higher than PSA. However, no significant correlation of uPM3 positivity was found with Gleason's grade, metastatic potential and pathological stage. Conclusion: Unlike serum PSA, uPM3 was found to be independent of prostate volume thereby having no false positives unlike raised PSA because of large benign prostate hypertrophy.
\end{abstract}

Keywords: uPM3, Molecular test in urine, Carcinoma prostate, Prostate Specific Antigen

\section{Introduction}

Prostate cancer incidence has been increasing in India. The outlook for prostate cancer has considerably changed in the last decade. Though uncommon in Asian countries, the incidence is increasing in our country. Currently, it ranks 5th in incidence and 4th in cancer mortality for men as per a study conducted in Mumbai [1]. Indeed an appreciable increase in the early detection of prostate cancer has been achieved [2]; however, it has not yetbeen demonstrated that the increased detection rate will decrease the prostate cancer-related mortality rates. A significant contribution to the early detection of prostate cancer has been the detection of Prostate Specific Antigen (PSA) and subsequent development of various immunological assays in serum. Serum PSA and digital rectal examination (DRE) are recognized as the foremost markers for detection of prostate cancer and can be used for screening selected populations of patients and for monitoring patients after therapy [2]. However,

Manuscript received: $26^{\text {th }}$ December 2016

Reviewed: $1^{\text {st }}$ January 2017

Author Corrected: $6^{\text {th }}$ January 2017

Accepted for Publication: $12^{\mathrm{th}}$ January 2017 serum PSA levels are regularly elevated in men with BPH (Benign Prostate Hypertrophy), prostatitis, and other non-malignant disorders, resulting in reduced specificity [3].

A better understanding of the molecular changes associated with the onset and progression of prostate cancer may provide a rational basis for the development of new diagnostic and prognostic tools as well as new targets for therapy. Likewise, the recent identification of critical biochemical pathways, including angiogenesis, programmedcell death, cell adhesion, and signal transduction have offered promising targets for new diagnostic and therapeutic approaches [4]. Telomerase activity is one of the most promising markers. High activity has been detected in the majority (90\%) of prostate tumors, whereas only low or absent activity was observed in normal and BPH tissues [5]. An alternative for telomerase activity: measurement of a new prostate cancer-specific gene, DD3 (PCA3) has been described recently. It has been hypothesized that because DD3 expression is the rate-limiting determinant 
of the telomerase enzyme [6], accurate quantification of mRNA of expressed copies may better differentiate between malignant and benign prostate growth than semi-quantitative telomerase activity measurements.

This gene produces mRNA/protein called uPM3 which is excreted in voided urine. DD3 is highly overexpressed in prostate cancer tissue in comparison to adjacent nonmalignant prostatic tissue thereby increasing the release of uPM3 mRNA in the urine [6, 7]. Other genes, such as hTERT, PSGR and PCGEM1, have recently been identified that have more prostatespecific expression $[8,9]$.

There was a need to correlate the presence of uPM3 mRNA in urine with the volume of prostatomegaly, number of nodules, metastasis and the Gleason's histopathological score. Our study aimed at doing the same. This study was planned in determining the specificity, sensitivity and predictive value of this new molecular test being done by reverse transcriptase method. There are very few Indian studies on the detection of molecular markers in prostatic cancer [10]. The introduction of molecular tests in early detection of prostate cancer in India will aid in reducing the incidence of mortality of this cancer.

\section{Materials and Methods}

Type of Study- This was a prospective randomized control study was carried out in a large tertiary care service hospital. 280 cases of prostatomegaly were included in the study.

Inclusion Criteria \& Sample Collection- All the symptomatic patients of prostatomegaly (confirmed by digital rectal examination- DRE) reporting to the urology clinic were included in the study. These patients after initial DRE (prostatic massage done during this examination) reported to the hospital laboratory. Serum was collected for total PSA estimation. The PSA was estimated by ELISA technique. On the same visit to the laboratory the patient passed urine (post prostatic massage) in a container $(20-30 \mathrm{ml})$ and centrifuged at $3000 \mathrm{rpm}$ for $10 \mathrm{~min}$. Urine deposit was mixed with an equal volume of phosphate buffer $(\mathrm{pH} 7.0)$ and then stored at $2^{\circ}$ to $8^{\circ} \mathrm{C}$.

The ethical review board of the hospital approved the study, and all patients provided written informed consent. The biopsy procedure was standardized: 6-8 cores guided by ultrasonography were taken. The biopsies (needle and radical prostatectomy) were fixed in $10 \%$ formalin and processed/stained in conventional method.

Statistical Analysis- Spearman correlation coefficient was used to correlate the presence/absence of uPM3 with the levels of serum PSA. A $2 \times 2$ table was constructed and Chi square test was used to find out the level of significant association between the presence of uPM3 in urine with various known prognostic markers (stage, number of nodules, volume of prostate, metastasis and Gleasons score).

Methodology of the molecular test- The uPM3 RTPCR was done in 3 stages.

Stage-1: (Isolation/Extraction Of High Purity MRNA From Urine Sample)-This step was carried out using EZNA Mag-Bind mRNA kit manufactured by OMEGA biotech. The centrifuged deposit was collected in nuclease free $1.5 \mathrm{ml}$ centrifuge tubes. The pellet was lysed in RNA-Solv reagent, $0.2 \mathrm{ml}$ chloroform was added and $80 \%$ of aquaeous phase was transferred into a new tube. Oligo (dT) magnetic beads was used for RNA extraction.

Stage-2: conversion of mRNA to cDNA- This step was carried out using RT-PCR\&GO kits (Fig No. 1). In a $0.2 \mathrm{ml}$ tube mix $5 \mu \mathrm{l}$ of mRNA extracted, $1 \mu \mathrm{l} 8$ random octamers, $4 \mu \mathrm{l}$ sterile water and $2 \mu \mathrm{l}$ DTT. The mixture was incubated for $5 \mathrm{~min}$ at $72^{\circ} \mathrm{C}$ and then to $42^{\circ} \mathrm{C}$ for $5 \mathrm{~min}$. Subsequently $8 \mu \mathrm{l}$ of RT-GO mastermix (inclusive of reverse transcriptase enzyme) was added. This mixture was incubated for $1 \mathrm{hr}$ at $42^{\circ} \mathrm{C}$ and reverse transciptase was inactivated by incubating the tube at $70^{\circ} \mathrm{C}$ for $15 \mathrm{~min}$.

Stage-3: Polymerase Chain Reaction- $5 \mu 1$ of cDNA was mixed with $2 \mu 1$ of 5 'primer, $2 \mu 1$ of 3 'primer, $5 \mu 1$ of taqGO mastermix (inclusive of taq polymerase enzyme, nucleotides, $\mathrm{MgCl} 2$ ) and $11 \mu \mathrm{l}$ of sterile water. DD3(uPM3)-specific primers: (a) forward primer (located in exon 1), 5'-AGATTTGTGGTGCTGCAG CC-3'; and (b) reverse primer (located in exon 3), 5'TCCTGCCCATCCTTT AAGG-3' \{GenBank accession number AF103907\}. To verify the quality of the cDNA synthesized, control reactions was performed using primers derived from the 2 microglobulin gene, a ubiquitous housekeeping gene: (a) forward primer (located in exon 2), 5'-AGCAGA GAA TGGAAAG TCAAA-3'; and (b) reverse primer (located in exon 4), 5'TGTTGATGTTGGATAAGA GAA-3'. The mixture was put in thermocycler with following parameters set. 


\section{Research Article}

$1 \mathrm{~min}$ of denaturation at $93^{\circ} \mathrm{C}, 1 \mathrm{~min}$ of annealing at 58 ${ }^{\circ} \mathrm{C}$ and finally $1 \mathrm{~min}$ of extension at $72{ }^{\circ} \mathrm{C} .35$ cycles of this setting were run. Final extension was done at $72{ }^{\circ} \mathrm{C}$ for 10min. The PCR products were put on agarose gel. The expected area for uPM3 was 356 bp and $\beta 2$ microglobulin was 578bp (Fig No.2).

\section{Results}

Out of 280 cases, 27 cases were diagnosed as cases of carcinoma prostate based on the histopathological report (needle biopsies- 20, radical prostatectomies-7). Fig no. 2 shows the RT-PCR results of few cases.

Clinic pathological- Fig No. 1: RT-PCR : Upper panel: uPM3 : Specimen 4 \& 16 showing positive band at 356 bp in a cases of prostate carcinoma. Lower panel: beta 2 microglobulin (internal control): all specimens showing positive band at $578 \mathrm{bp}$ for $\beta 2 \mathrm{~m}$.

\section{123456789101112131415161718 M (bos)}

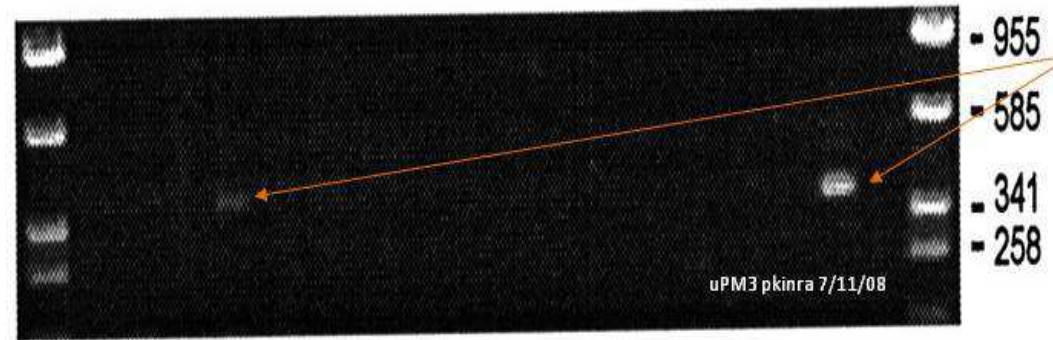

Positive band for UPM3

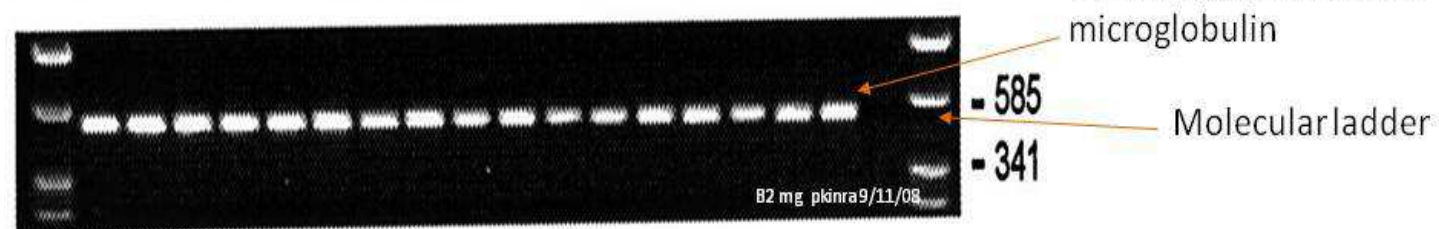

Fig No.2:

Patients ranged from 53 to 75 years (mean 64.11 years). 23/27 cases were positive for uPM3 testing. Mean serum PSA was $28.93 \mathrm{ng} / \mathrm{ml}$ (range 2.3-83.4 ng/ml). Mean cancer volume was $7.88 \mathrm{cc}$ (range $0.5-13.9 \mathrm{cc}$ ). The volume of the same was estimated by trans-rectal ultrasonography. In 25 cases, prostate cancer involved the transition and the peripheral zones while in the remaining two cases tumour was limited to the peripheral zone. Multicentricity, defined by the presence of two or more independent tumors, was noted in 23/27 cases (85.1\%). Mean Gleason score was 7.5 (range 59). Pathologic stage was pT2 for 19 cases and pT3 for the remaining eight cases. There were 3 cases of prostatomegaly wherein no tumour was picked up on TRUS guided biopsy however the uPM3 was positive.

A total of 33/280 cases had PIN (high grade-10 and low grade-23). Patients ranged from 47 to 70 years (mean 53.5 years). 3/33 cases of PIN were positive for uPM3 RT-PCR (High Grade-2, Low grade -1). Mean serum PSA was $13.4 \mathrm{ng} / \mathrm{ml}$ (range 1.9 - $37.5 \mathrm{ng} / \mathrm{ml}$ ). The uPM3 positivity in cases of carcinoma and PIN is depicted in Table No. 1.

Table No.-1: depicting the positivity of uPM3 in premalignant and malignant conditions of prostate.

\begin{tabular}{|c|c|c|c|c|}
\hline & $\begin{array}{c}\text { No. of cases upM3 } \\
\text { positive }\end{array}$ & No. of cases uPM3 negative & Total & \% positivity \\
\hline Low grade PIN & 1 & 23 & 24 & $4.1 \%$ \\
\hline High grade PIN & 2 & 7 & 9 & $22.2 \%$ \\
\hline Carcinoma prostate & 23 & 4 & 27 & $85.1 \%$ \\
\hline
\end{tabular}

The study showed a diagnostic accuracy of $91 \%$. Out of 27 cases of prostate cancer confirmed by histopathology, 23 $(85.1 \%)$ had shown a band in gel electrophoresis for uPM3 mRNA. True Positives= 23, False Negative= 4 . Out of 33 cases of PIN, three cases showed uPM3 band. The efficacy of this test was calculated using $2 \times 2$ table (Table No.2). 


\section{Research Article}

Table No.-2: 2x2 Table construed to analyze the effectiveness of this new molecular test.

\begin{tabular}{|c|c|c|c|}
\hline uPM3 & \multicolumn{2}{|c|}{ Histopatholgically Diagnosed Carcinoma } & Total \\
\hline Present & Present & Absent & 26 \\
\hline Absent & 23 & 250 & 254 \\
\hline Total & 4 & 253 & 280 \\
\hline
\end{tabular}

Sensitivity $=85.18 \%$, Specificity $=98.81 \%$, Positive Predictive Value $=88.46 \%$, Negative Predictive Value $=98.42 \%$, Positive Likelihood ratio:72, 95\% confidence interval: [71\%,96\%], Negative Likelihood ratio:0.15, 95\% [1\%,4\%].

The correlation of uPM3 with serum PSA was carried out keeping the tissue diagnosis as gold standard. [Table No.3]. ROC was adopted to find out the utility of this molecular test. The AUC (area under curve) was significantly high [Figure no. 3]. The AUC of uPM3 is 0.98 vis- a vis that of PSA calculated as 0.7902 .

\section{PSA}

Table No. -3: Statistical analysis of uPM3 compared to serum PSA.

\begin{tabular}{|c|c|c|c|}
\hline & Confirmed cases by HPE & Statistical data & $\begin{array}{c}\text { 95\% Confidence } \\
\text { interval }\end{array}$ \\
\hline PSA (< 10) & 10 & Sensitivity PSA & $62.96 \%$ \\
\hline PSA (> 10) & 17 & Specificity PSA & $83.21 \%$ \\
\hline & & Positive Predictive Value PSA & $26.56 \%$ \\
\hline uPM3 Negative & 4 & Negative Predictive value PSA & $95.88 \%$ \\
\hline uPM3 Positive & 23 & Sensitivity uPM3 & $85.18 \%$ \\
\hline & & Specificity uPM3 & $98.78 \%$ \\
\hline & & Positive Predictive Value uPM3 & $88.46 \%$ \\
\hline
\end{tabular}

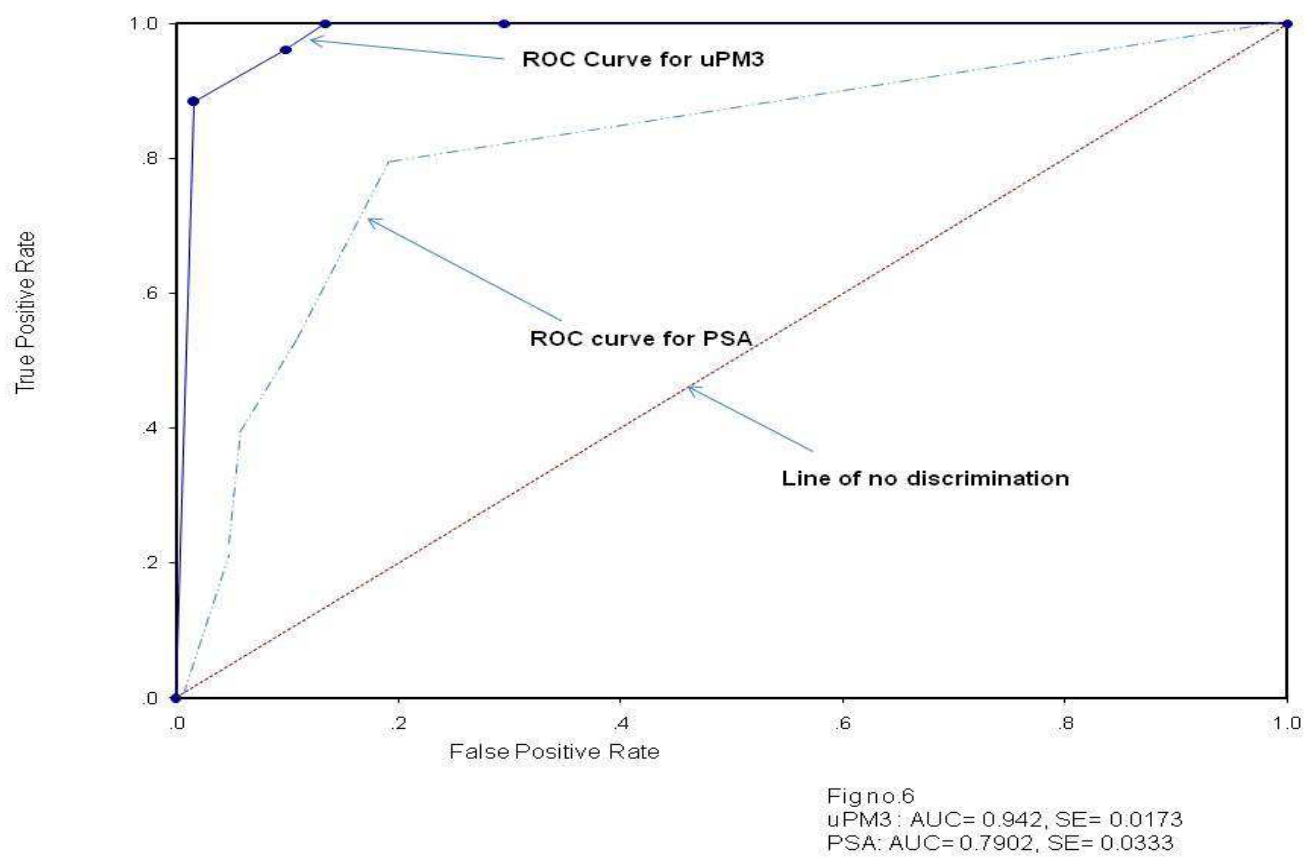

Fig No.3: ROC Curve for uPM3 


\section{Research Article}

The further statistical analysis showed a statistical significant difference in sensitivity and positive predictive value of uPM3 molecular test over the serum prostate specific antigen estimation (Standard error of estimate $=5.713$; $\mathrm{t}$ test of significance $=1.551$, two tailed probability $=0.2661$ )

uPM3 was able to detect 6 cases of carcinoma prostate with serum PSA below $10 \mathrm{ng} / \mathrm{mL}$. These six cases would have eventually turned out to higher stage prostate cancer if detection was done later based solely on serum PSA. However 3/27 carcinoma cases were detected negative by uPM3 but positive by PSA and histopathology. The positive and negative likelihood ratio of UPM3 is 52.81 and 0.15 respectively. The disease prevalence is $9.64 \%$ (out of 100 prostatomegaly cases 9.64 had carcinoma). This high rate can be explained by including numerous worked up cases referred from peripheral hospitals.

Statistical difference was found in serum PSA positivity when compared to different grades of volume of tumour (PSA: $\mathrm{p}=0.0201$, Degree of freedom $=2$, Chi square 7.81) [Table No.4]. In fact, it was apparent that the PSA value is higher in tumours with large volume; however uPM3 was not influenced by the same (uPM3: p=0.0931, Degree of freedom=2, Chi square 4.747) [Table No.4]. The statistical analysis of uPM3 \& PSA positivity versus number of nodules showed a significant increase in uPM3 positivity and not in PSA positivity as the number of nodules increased. No notable correlation was seen between the stage of the disease, metastatic potential, and Gleasons score when compared to positivity of uPM3 [Table No.4].

Table No.-4: Statistical analysis of uPM3 \& serum PSA >10ng/mL versus number of nodules, metastasis, volume of tumour, stage \& Gleasons score.

\begin{tabular}{|c|c|c|c|c|c|}
\hline Variables & $\begin{array}{c}\text { Total } \\
\text { Number Of } \\
\text { cases }\end{array}$ & $\begin{array}{c}\text { uPM3 } \\
\text { Positive/Neg } \\
\text { ative }\end{array}$ & $P$ value (Chi square) & $\begin{array}{l}\text { PSA }>10 \\
\mathrm{ng} / \mathrm{mL} /< \\
10 \mathrm{ng} / \mathrm{mL}\end{array}$ & $P$ value (Chi square) \\
\hline \multicolumn{6}{|c|}{ Number of Nodules } \\
\hline 1 & 4 & $2 / 2$ & \multirow{3}{*}{$\begin{array}{c}\mathrm{p}=0.0342 \\
\text { Degree of freedom=2 } \\
\text { Chi square } 6.75\end{array}$} & $2 / 2$ & \multirow{3}{*}{$\begin{array}{c}\mathrm{p}=0.215 \\
\text { Degree of freedom=2 } \\
\text { Chi square-3.074 }\end{array}$} \\
\hline $2-3$ & 9 & $7 / 2$ & & $4 / 5$ & \\
\hline 4 and $>4$ & 14 & $14 / 0$ & & $11 / 3$ & \\
\hline \multicolumn{6}{|c|}{ Metastasis } \\
\hline Present & 6 & $6 / 0$ & \multirow{2}{*}{$\begin{array}{c}\mathrm{p}=0.2466 \\
\text { Degree of freedom=1 } \\
\text { Chi square } 1.342\end{array}$} & $4 / 2$ & \multirow{2}{*}{$\begin{array}{c}\mathrm{p}=0.832 \\
\text { Degree of freedom }=1 \\
\text { Chi square } 0.045\end{array}$} \\
\hline Absent & 21 & $17 / 4$ & & $13 / 8$ & \\
\hline \multicolumn{6}{|c|}{ Volume of Tumour } \\
\hline$<5 \mathrm{cc}$ & 15 & $14 / 1$ & \multirow{3}{*}{$\begin{array}{c}\mathrm{p}=0.0931 \\
\text { Degree of freedom=2 } \\
\text { Chi square } 4.747\end{array}$} & $6 / 9$ & \multirow{3}{*}{$\begin{array}{c}\mathrm{p}=0.0201 \\
\text { Degree of freedom=2 } \\
\text { Chi square } 7.81\end{array}$} \\
\hline $5-10 \mathrm{cc}$ & 8 & $5 / 3$ & & $7 / 1$ & \\
\hline $10 \mathrm{cc}$ & 4 & $4 / 0$ & & $4 / 0$ & \\
\hline \multicolumn{6}{|c|}{ Stage } \\
\hline T2a & 2 & $1 / 1$ & \multirow{4}{*}{$\begin{array}{c}\mathrm{p}=0.333 \\
\text { Degree of freedom=1 } \\
\text { (Stage2 \& } 3 \text { clubbed) } \\
\text { Chi square } 0.934\end{array}$} & $1 / 1$ & \multirow{4}{*}{$\begin{array}{c}\mathrm{p}=0.974 \\
\text { Degree of freedom=1 } \\
\text { (Stage2 \& } 3 \text { clubbed) } \\
\text { Chi square } 0.001\end{array}$} \\
\hline T2b & 1 & $1 / 0$ & & $0 / 1$ & \\
\hline T2c & 16 & $15 / 1$ & & $11 / 5$ & \\
\hline T3a\&b & 8 & $6 / 2$ & & $5 / 3$ & \\
\hline \multicolumn{6}{|c|}{ Gleason's Score } \\
\hline $5,6,7$ & 18 & $14 / 4$ & \multirow{3}{*}{$\begin{array}{c}\mathrm{p}=0.633 \\
\text { Degree of freedom=2 } \\
\text { (Gleasons } 5 / 6 \& 7 / 8 \\
\text { clubbed) } \\
\text { Chi square } 0.912\end{array}$} & $11 / 7$ & \multirow{3}{*}{$\begin{array}{c}\mathrm{p}=0.331 \\
\text { Degree of freedom=2 } \\
\text { (Gleasons } 5 / 6 \& 7 / 8 \\
\text { clubbed) } \\
\text { Chi square } 0.688\end{array}$} \\
\hline 8 & 5 & $5 / 0$ & & $4 / 1$ & \\
\hline 9 & 4 & $4 / 0$ & & $4 / 0$ & \\
\hline
\end{tabular}

The presence of beta 2 microglobulin (by RT-PCR) in the urine sample to confirm the presence of prostate shedded cells in the urine sample collected post prostatic massage is shown in table no.5. 
Research Article

Table No.- 5: Percentage positivity of post prostatic massage urine sample for beta 2 microglobulin (housekeeping gene).

\begin{tabular}{|c|c|c|c|}
\hline Type of Case & Total number of cases & $\begin{array}{c}\text { Presence of beta 2 } \\
\text { microglobulin }\end{array}$ & \% positivity \\
\hline Prostate Carcinoma & 27 & 25 & 92.5 \\
\hline PIN High Grade & 10 & 9 & 90 \\
\hline PIN Low Grade & 23 & 20 & 86.9 \\
\hline Prostatitis & 20 & 18 & 90 \\
\hline BPH & 20 & 16 & 80 \\
\hline Overall cell yield & & & 87 \\
\hline
\end{tabular}

\section{Discussion}

In many developed countries, prostate cancer is the second most important cause of cancer-related deaths among men. In a year approximately 232,090 men in the USA were newly diagnosed with prostate cancer. Incidence of prostate cancer is also increasing in India [11]. Numerous factors like contrasting genetic, environmental and dietary influences may be accountable for the low incidence of prostate cancer amongst Asian populations when compared to Western world.

Since PSA's first clinical application, it has shown to be the most important tool in the detection, staging and monitoring of prostate cancer. Since 1997, the European Randomised Study of Screening for Prostate Cancer (ERSPC), Rotterdam section, accepted serum PSA values $\geq 3 \mathrm{ng} / \mathrm{ml}$ as the standard biopsy indication, irrespective of DRE or TRUS (trans-rectal ultrasonography) findings [12]. A large multi-centre prostate cancer screening trial showed that men with serum PSA values between 3 and $10 \mathrm{ng} / \mathrm{ml}$ most likely have clinically localized disease and would benefit from curative treatment [13]. However, only one in four men with serum PSA values between 3 and $10 \mathrm{ng} / \mathrm{ml}$ has prostate cancer upon biopsy resulting in a negative biopsy rate of $70-80 \%$.

The low specificity of the serum PSA test is a outcome of the fact that increased PSA levels have been detected in men with $\mathrm{BPH}$ and prostatitis and is not a prostate cancer-specific event. Furthermore, PSA screening fails to detect a small percentage of highly aggressive prostate cancers, that are likely to be life threatening.

There are many more serum markers like hK2, Hepsin, 50-kDa protein AMACR immunereactivity, CRISP-3, \&hK11 available in the diagnostic bandwagon but have the same disadvantages of PSA.
The promising novel approach is based on the molecular detection of prostate cancer cells in urine obtained after prostatic massage by measuring cancerspecific markers such as GSTP1, telomerase, or PCA3/DD3 (uPM3) RNA by RT-PCR [14]. PCA3/DD3 (uPM3) is one of the most prostate cancer-specific genes described so far, with over-expression in $95 \%$ of cancers tested and a median 66-fold up-regulation compared with adjacent non-neoplastic prostatic tissues $[6,15]$.

The quantitative reverse transcriptase-polymerase chain reaction analysis of PCA3/DD3 (uPM3) gene in urine samples obtained after prostatic massage showed $67 \%$ sensitivity and $80 \%$ specificity for prostate cancer detection in a recent single-institution study [16]. Studies comparing the value of PCA3/DD3 (uPM3) as a prostate cancer biomarker with that of the telomerase transcriptase (hTERT gene) found the former to be overall superior, even in a background of abundant nonneoplastic prostate tissue [15]. Our study showed sensitivity and specificity of uPM3 keeping histopathology as gold standard was $85.18 \%$ and $98.78 \%$ respectively. The high specificity of the uPM3 test was likely a result of the very high discriminating power of the gene expression in prostatic cancer cells.

Positive predictive value was $88.46 \%$ and negative predictive value was $98.38 \%$. The PCA3 gene, a noncoding segment of mRNA located on chromosome 9q21-22, is over-expressed by prostate cancer cells in comparison with all other cells studied. The differential expression is great, permitting detection of the gene in nuclear material from cancer cells shed into urine after an attentive DRE.

Fradet $\mathrm{Y}$ et al studied the uPM3 assay from 517 men undergoing prostate needle biopsy at 5 medical centers 
[17]. The authors showed that the overall area under the ROC curve for predicting the presence of prostate cancer for the uPM3 test was 0.86-similar to the value seen in our study: 0.9842. Hessels et al suggested that even when the amount of cancer in the tissue sample was very miniscule $(<10 \%)$, elevated upM3 can be detected [16]. This reiterates the importance of this molecular test. Further studies have been carried out to correlate uPM3 with other molecular markers like hTERT. UPM3 showed much better diagnostic characteristics than hTERT, with AUC-ROC values of 0.98 for UPM3 and 0.88 for hTERT. The median increase in mRNA expression from nonmalignant to malignant tissues was only 6-fold for hTERT gene, however the median of uPM3 increase was 34-fold [18]. This difference is highly significant.

The statistical analysis of this study showed a significant increase in percentage positivity of uPM3 as the number of nodules increased $\left(p=0.0342 \chi^{2}\right)$ compared to PSA $\left(p=0.215 \chi^{2}\right)$. This signifies the importance of UPM3 over PSA in predicting prognosis in low focal lesions of prostate. Ruijter et al in a series of 151 radical prostatectomy specimens showed that $43.7 \%$ of the prostates contained a single carcinoma, $31.1 \%$ had 2 separate foci and the balance $25.2 \%$ contained 3 to 6 tumours [19].

Multifocality was greatest among tumours with the lowest mean volumes. It is likely, therefore, that the prediction of prognosis for patients with prostatic cancer is greatly influenced by tumor multifocality. In our study there were 4 cases out of 27 who were missed by uPM3 thereby confirming the corrections to be done in the methodology and verifying the housekeeper genes more stringently. Out of these 4 cases two cases had not shown beta-2 microglobulin band thereby highlighting faulty sample collection. On the contrary there were 3 cases which showed detectable uPM3 but no cancer trace on biopsy. $1 / 3$ of these cases was lost to follow up.

Another one developed high grade PIN after a period of 2 years. One case still does not show any features of carcinoma on 3 year follow-up. This shows that we succeeded in picking up one case early by molecular test, much earlier than the histopathology could detect the malignancy.

The tumour volume is one of the key prognostic markers of prostate cancer outcome [20]. Statistical difference was found in serum PSA positivity $\left(\mathrm{p}=0.0201 \chi^{2}\right)$ and not in uPM3 $\left(\mathrm{p}=0.0931 \chi^{2}\right)$ when compared to different grades of volume of tumour. It was apparent that the PSA value scores were much higher compared to uPM3 in tumours with large volume. Contrarily this highlights the advantage of using uPM3 over PSA as the volume does not affect the parameter. This drawback of PSA is notable when the test is false positive in large volume benign lesions of prostate. No notable correlation was seen between the stage of the disease, metastatic potential, and Gleasons score when compared to positivity of uPM3. Hessels D and van Gills $M$ showed similar finding wherein in their cohort they could not find a correlation between uPM3 and clinical stage or pathological stage [21].

Using differential display analysis to compare the mRNA expression patterns of tumor tissue and non neoplastic tissue, we could not detect uPM3 expression in any of prostatitis and BPH studied. This indicates that the expression of UPM3 is restricted to the neoplastic prostate tissue. Vis-a-vis the serum PSA, uPM3 detection had a significant high sensitivity and positive predictive value.

\section{Conclusion}

Our study has shown that uPM3 will have profound value in patients with equivocal PSA range of 4 to 10 $\mathrm{ng} / \mathrm{mL}$ and negative initial biopsy, because of very high negative predictive value $(98.38 \%)$ resulting from the high specificity of the test $(98.78 \%)$.

It is to be expected that urologists worldwide will perform the DRE differently, which will inevitably result in different cell yields. Standardization of the attentive digital rectal examination, therefore, deserves attention.

Extension with a panel of other prostate cancer specific and/or progression markers would further extend the potential value of such tests. Future investigations should address the potential prognostic value of the uPM3 test to determine cancer aggressiveness using a quantitative RT-PCR.

Funding: Nil, Conflict of interest: None initiated, Permission from IRB: Yes

\section{References}

1. Yeole BB, Jussawalla DJ. Descriptive epidemiology of bone cancer in greater Bombay. Indian $\mathbf{J}$ Cancer. 1998 Sep; 35(3):101-6. 
2. Arcangeli CG, Ornstein DK, Keetch DW, Andriole GL. Prostate-specific antigen as a screening test for prostate cancer. The United States experience. Urol Clin North Am.1997 May; 24 (2): 299-306. Review.

3. Pannek J, Partin AW. Prostate-specific antigen: what's new in 1997. Oncology (Williston Park). 1997 Sep; 11(9):1273-8; discussion 1279-82.

4. Schalken JA, Hessels D, Verhaegh G. New targets for therapy in prostate cancer: differential display code 3 (DD3(PCA3)), a highly prostate cancer-specific gene. Urology. 2003 Nov;62(5 Suppl 1):34-43.

5. Caldarera E, Crooks NH, Muir GH, PavoneMacaluso M, Carmichael PL. An appraisal of telomerase activity in benign prostatic hyperplasia. Prostate. 2000 Nov 1;45(3):267-70.

6. Bussemakers MJ, van Bokhoven A, Verhaegh GW, Smit FP, Karthaus HF, Schalken JA, Debruyne FM, Ru N, Isaacs WB. DD3: a new prostate-specific gene, highly overexpressed in prostate cancer. Cancer Res. 1999 Dec 1;59(23):5975-9.

7. Hakalahti L, Vihko P, Henttu P, Autio-Harmainen H, Soini Y, Vihko R. Evaluation of PAP and PSA gene expression in prostatic hyperplasia and prostatic carcinoma using northern-blot analyses, in situ hybridization and immunohistochemical stainings with monoclonal and bispecific antibodies. Int $\mathrm{J}$ Cancer. 1993 Oct 21;55(4):590-7.

8. $\mathrm{Xu}$ LL, Stackhouse BG, Florence K, Zhang W, Shanmugam N, Sesterhenn IA, Zou Z, Srikantan V, Augustus M, Roschke V, Carter K, McLeod DG, Moul JW, Soppett D, Srivastava S. PSGR, a novel prostatespecific gene with homology to a $G$ protein-coupled receptor, is overexpressed in prostate cancer. Cancer Res. 2000 Dec 1;60(23):6568-72.

9. Srikantan V, Zou Z, Petrovics G, Xu L, Augustus M, Davis L, Livezey JR,Connell T, Sesterhenn IA, Yoshino K, Buzard GS, Mostofi FK, McLeod DG, Moul JW, Srivastava S. PCGEM1, a prostate-specific gene, is overexpressed in prostate cancer. Proc Natl Acad Sci U S A. 2000 Oct 24;97(22):12216-21.

10. Srivastava DS, Mandhani A, Mittal B, Mittal RD. Genetic polymorphism of glutathione S-transferase genes (GSTM1, GSTT1 and GSTP1) and susceptibility to prostate cancer in Northern India. BJU Int. 2005 Jan; 95(1):170-3.

11. Parkin DM, Bray FI, Devesa SS. Cancer burden in the year 2000. The global picture. Eur J Cancer. 2001 Oct; 37 Suppl 8:S4-66.

12. Schröder FH. Diagnosis, characterization and potential clinical relevance of prostate cancer detected at low PSA ranges.Eur Urol.2001Apr;39 Suppl 4: 49-53.

13. Catalona WJ, Smith DS, Ornstein DK. Prostate cancer detection in men with serum PSA concentrations of 2.6 to $4.0 \mathrm{ng} / \mathrm{mL}$ and benign prostate examination. Enhancement of specificity with free PSA measurements. JAMA. 1997 May 14; 277 (18): 1452-5.

14. Goessl C, Müller M, Heicappell R, Krause H, Straub B, Schrader M, Miller K.DNA-based detection of prostate cancer in urine after prostatic massage. Urology. 2001 Sep;58(3):335-8.

15. de Kok JB, Verhaegh GW, Roelofs RW, Hessels D, Kiemeney LA, Aalders TW, Swinkels DW, Schalken JA. DD3(PCA3), a very sensitive and specific marker to detect prostate tumors. Cancer Res. 2002 May 1;62 (9): 2695-8.

16. Hessels D, Klein Gunnewiek JM, van Oort I, Karthaus HF, van Leenders GJ, van Balken B, Kiemeney LA, Witjes JA, Schalken JA. DD3(PCA3)based molecular urine analysis for the diagnosis of prostate cancer. Eur Urol. 2003 Jul;44(1):8-15; discussion 15-6.

17. Fradet Y, Saad F, Aprikian A, Dessureault J, Elhilali M, Trudel C, Mâsse B, Piché L, Chypre C. uPM3, a new molecular urine test for the detection of prostate cancer. Urology. 2004 Aug;64(2):311-5; discussion 315-6.

18. Broccoli D, Young JW, de Lange T. Telomerase activity in normal and malignant hematopoietic cells. Proc. Natl Acad Sci 1995 Sep; 92 (20): 9082-86.

19. Ruijter ET, Miller GJ, Aalders TW, van de Kaa CA, Schalken JA, Debruyne FM,Boon ME. Rapid microwave-stimulated fixation of entire prostatectomy specimens.Biomed-II MPC Study Group. J Pathol. 1997 Nov;183(3):369-75. 
20. Sebo TJ, Cheville JC, Riehle DL, Lohse CM, Pankratz VS, Myers RP, Blute ML, Zincke H. Predicting prostate carcinoma volume and stage at radical prostatectomy by assessing needle biopsy specimens for percent surface area and cores positive for carcinoma, perineural invasion, Gleason score, DNA ploidy and proliferation, and preoperative serum prostate specific antigen: a report of 454 cases. Cancer. 2001 Jun 1;91(11):2196-204.
21. Hessels D, van Gils MP, van Hooij O, Jannink SA, Witjes JA, Verhaegh GW, Schalken JA. Predictive value of PCA3 in urinary sediments in determining clinico-pathological characteristics of prostate cancer. Prostate. 2010 Jan 1; 70 (1):10-6. doi: 10.1002/ pros.21032.

\section{How to cite this article?}

Prateek K, B Sivaramakrishna, Rastogi V. Prostate cancer diagnosis by detection of uPM3 in urine. Trop J Path Micro 2017;3(1):26-34.doi: 10.17511/jopm.2017.i1.05. 